\title{
Technology in children's picture books as an agent for reinforcing or challenging traditional gender stereotypes
}

\author{
Cecilia Axell ${ }^{1}$ (D) . Johan Boström ${ }^{2}$
}

Accepted: 1 July 2019 / Published online: 11 July 2019

(c) The Author(s) 2019

\begin{abstract}
Technology is a field with strong connections to the female/male dichotomy. Children start to stereotype everyday life regarding this dichotomy as early as the age of two. The preschool, through its activities - among them reading aloud from picture books-is an arena where societal norms can be either preserved or challenged. Books about different artefacts, e.g. cars, airplanes and boats, often serve as an introduction for children about the human application of technology and may influence how they identify and categorise the technology they encounter in everyday life. The aim of this study was to investigate the technological content in a selection of picture books from a gender perspective. Since preschools in Sweden often use books from libraries in their daily activities, the empirical material was derived from the library sections Facts for youngsters and Technology for youngsters, aimed at children aged 1-3 and 3-6. A thematic analysis was used to discover the dominant themes within the books. The results show that there is a focus on how separate artefacts function but no detailed explanation of how these artefacts are connected or what kind of implications they have in a societal context. There also seems to be an emphasis on traditionally masculine coded technology.
\end{abstract}

Keywords Technology education · Preschool · Picture books · Gender · Artefacts · Equality

\section{Introduction}

To navigate their daily life in an increasingly technologically intensive society, citizens need knowledge and skills in the form of highly developed technological literacy (Rohaan et al. 2010; Siu and Lam 2005; Turja et al. 2009). Without this knowledge, citizens will not be able to make deliberate democratic choices (Keirl 2006). The Swedish preschool curriculum stresses the importance of technology education, and states that the goal is to ensure that children develop their ability to identify and explore technology in everyday

Cecilia Axell

cecilia.axell@liu.se

Johan Boström

johan.bostrom@lnu.se

1 Department of Social and Welfare Studies, Linköping University, 60174 Norrköping, Sweden

2 Department of Physics and Electrical Engineering, Linnaeus University, 35195 Växjö, Sweden 
life (Swedish National Agency for Education 2018, p. 14). In the curriculum it is also stated that the preschool has a responsibility to counteract gender patterns that limit children's development, choices and learning, and that children should be given the opportunity to develop their abilities and interests regardless of gender affiliation (p. 7). However, research shows that this is very complex goal for preschool teachers to handle (e.g. Boström 2018; Eidevald 2009).

One challenge is that there is a strong relationship between technology and masculinity in today's society (e.g. Faulkner 2001; Mellström 2003, 2004; Oldenziel 1999; Wajcman 1991). Historically, technology has often been considered a male area of interest, and this notion has for the most part gone unchallenged. However, the societal view of gender and technology needs to be understood from a perspective that these two concepts affect, shape and construct each other (Oldenziel 1999). The notion that technology is an exclusively male domain, while having historical roots, is a relatively new one which can be traced back to the Western industrial revolution and the rise of the engineer as a male role model (Berner 1999; Oldenziel 1999). Before this, a lot of different occupations, inventions, production areas or knowledge could be placed in the technological domain, or as Oldenziel (1999) puts it:

Language, quilts or corsets, all important objects of women's inventive activity in the nineteenth century, do not come readily to contemporary minds as significant inventions or as markers of technology today, yet they once were. An early nineteenth-century speaker could discuss manufacturing, industry, and industriousness, referring to any kind of production mechanical or otherwise that could even include agriculture; could mention science and useful knowledge in one breath without sensing any contradiction, could marvel about the wonderful inventions and discoveries that ran the whole gamut from language to mechanical devices; and could speak of technology referring to academic knowledge as well as to the skills of millers, bakers, farmers, teachers, and innkeepers. (p. 19)

During the twentieth century, however, engineers started to influence and lay claim to the definition of technology. This was done not only by excluding females from vocations and educational institutions, but also through cultural narratives and discourses of what it meant to be a technologist and/or an inventor, and what could be interpreted as technological knowledge and skills. In this process, men were hailed as the technological heroes and women were put in the role of the silent bystander. Enterprises involving men, such as building cars, bridges and planes, were put at the top of the hierarchy of technology, while

[...] agricultural production, non-mechanical devices, languages, teachers, farmers, bonnets, and corsets were banished to the basement of the modern classification system of technology. (Oldenziel, 1999, p. 19)

This a pattern that still pervades today; in most industrialised countries the majority of engineers (and scientists) are men (Blickenstaff 2006). There is also a clear distinction between feminine coded and masculine coded technology in the societal discourse. The former is often described as "soft", while the latter is described as "hard". The "soft" technology (i.e. women's work, knowledge and everyday artefacts) is often closer to everyday labour and is not even considered to be technology by all people. In this vein, many traditionally feminine occupations are described as non-technological, even though the person carrying out the work needs to be equipped with a wide array of technological knowledge 
and know-how. Therefore, gender coded artefacts and vocational roles act as agents that reinforce gender stereotypes (Berner 2004; Freeman 2007).

This may be connected to the fact that children's views of gender form early in life, and as early as the age of 2 they begin to define themselves as "girl" or "boy" (e.g. Freeman 2007; Lyon 1991; Trepanier-Street and Romatowski 1999; Sandnabba and Ahlberg 1999; Turja et al. 2009). Children observe how the adults around them categorise things according to the female/male dichotomy, and through this they develop an understanding of gender-appropriate behaviour regarding toys, vocation and leisure activities (Kimmel 2000; Browne and Ross 1991; Freeman 2007; Lyon 1991; MacNaughton 1997; Raag and Rackliff 1998; Trepanier-Street and Romatowski 1999).

Gender differences in attitudes toward technology have long been a concern in education, and research indicates that a gender gap still persists (e.g. Bain and Rice 2006; Cai et al. 2017; Murphy 2006; Nisbet et al. 1998; Svenningsson et al. 2018; Volk and Ming 1999; Volman et al. 1995). The norm has been that men are expected to have a higher degree of knowledge in technology as well as confidence with technological artefacts. Norms like this have been a hindrance for women to approach technology (Cockburn 1985; Cockburn and Ormrud 1983; Oldenziel 1999).

One way in which these norms can be challenged or reinforced is through the literature with which children come into contact. Reading aloud has a long tradition in Swedish preschools and often involves books from public libraries (Kåreland 2005; Simonsson 2004). A Swedish government investigation states that preschool, through its activities such as reading aloud, is an arena where societal norms can be either preserved or challenged (SOU 2006:75). Since children's literature is a way for one generation to transmit cultural values to the next, the content of these books has the capacity to influence children's views of the world and themselves (Crisp and Hiller 2011; Gooden and Gooden 2001; Hellsing 1999; Kåreland 2005, 2013; Reynolds 2011), for example regarding what society deems as appropriate behaviour for women and men (Crisp and Hiller 2011; Oskamp et al. 1996; Trepanier-Street and Romatowski 1999).

Gender stereotyping and the under-representation of girls and women in children's picture books have been documented in previous research (e.g. Axell 2015; Clark et al. 2003; Hamilton et al. 2006; Nikolajeva 2004; Paynter 2011). Girls have generally been portrayed as passive, as waiting for the adventure to come to them, while boys have been portrayed as energetic, as "doers" (Kåreland 2005; Pearson 2011; Ross Johnston 2011). During the late 1990s and the early 2000s there was a debate in Sweden about the lack of varied portrayals of girls in picture books. The absence of female characters created a demand for girls' stories that would be in tune with a contemporary view of gender. Nowadays, this imbalance in picture books is considered by some to have been equalised, while others believe it is still a problem (Nikolajeva 2000; Kåreland 2005). For example, Hamilton et al. (2006) found that most adult characters in children's books could be found in traditional stereotypical occupations. They also found that males had a wider range of occupations than females. If a stereotypical view of gender is conveyed in books (as documented by Axell 2015; Clark et al. 2003; Hamilton et al. 2006; Nikolajeva 2004; Paynter 2011), this may contribute to socialising children into traditional roles and limiting their interest in other activities that may also suit them (Gooden and Gooden 2001; Oskamp et al. 1996).

Literature can thus be regarded as both a mediator for what is considered to be valuable technological knowledge and a teaching aid in technology education. Although some research has been carried out regarding the relationships between technology, society, culture and literature in regard to younger readers (Axell 2015; Axell 2017a, b; Axell et al. 
2014; Foster 2009), this perspective has generally been explored to a limited extent (Westin $2003 \mathrm{a}, \mathrm{b}$ ). However, in the adjacent field of science education there seems to be a growing consensus among researchers that children's literature can be used to foster interest and create positive attitudes towards learning about science in early childhood education (see e.g. Sackes et al. 2009; Monhardt and Monhardt 2006; Trundle and Troland 2005). McLean et al. (2015) indicate that children's literature may offer a way for early childhood teachers to develop confidence and competence to teach science by inquiry, but overall research on how technology is portrayed in children's fiction is still in its infancy, as is research regarding the use of fiction in the technology classroom (Axell 2015, 2017a, b).

The text and pictures in books can be viewed as qualitative information. Like all texts, children's books are culturally coded, consciously as well as unconsciously, implicitly and explicitly. Cultural codes regarding gender may be so deeply ingrained and pervasive that they are not recognised by those who hold them (Ross Johnston 2011).

Consequently, the aim of this study is to investigate the technological content in a selection of picture books from a gender perspective. More specifically:

- What kind of different portrayals of technology can be found in the books under investigation and how do these relate to gender?

- In what way can these portrayals act as agents for reinforcing or challenging gender stereotypes?

\section{Methodology}

To narrow down the empirical material, we chose to examine picture books from the library sections Facts for youngsters and Technology for youngsters at four different libraries in three Swedish cities. All of the books in these sections were perused, and those with technological content (i.e. the books which contained manmade artefacts and/or people interacting with manmade artefacts) were singled out for further analysis. This resulted in 180 books aimed at the age groups $1-3$ and 3-6. During our visits to the libraries some of the books with technological content may of course have been on loan and therefore excluded from the empirical material. Due to our large sample of books, however, this should not pose a problem.

We used a thematic analysis to identify dominant themes and patterns in the books. A thematic analysis "minimally organizes and describes your data set in (rich) detail" (Braun and Clarke 2008, p. 79) and is useful for interpreting various aspects of a research topic (Boyatzis 1998). A thematic analysis seeks to unearth themes at different levels, and the aim is to explore the understanding of an issue, rather than to reconcile conflicting definitions of an idea (Attride-Stirling 2001). As Braun and Clarke (2008) note, 'the 'keyness' of a theme is not necessarily dependent on quantifiable measures, but rather on whether it captures something important in relation to the overall research question" (p. 82). Based on this, the decision to use a thematic analysis was twofold; firstly, it is a way of processing qualitative information-the words and pictures in the picture books can be viewed as qualitative information carrying cultural values; secondly, both technology and gender structures are complex and can be viewed from a multitude of perspectives-a thematic analysis allows for several possible interpretations (e.g. Boyatzis 1998). When analysing 
the technology content in the books we took Ihde's (1993) broad definition of technology as our point of departure:

1. Technology has some kind of concrete component.

2. Humans use these components in some kind of praxes.

3. There is a relation between the humans and the technology (i.e. using, designing, making and modifying).

In picture books, the message to the reader is mediated through an interaction between text and pictures. Therefore, the analysis was performed using a holistic interpretation of image and text (Hallberg 1982, 2008). According to Björndahl (2005), analysing is a subjective endeavour where the researcher picks out content of particular importance; it is impossible to analyse everything in a certain situation. According to Braun and Clarke (2008), the process of doing a thematic analysis can be broken down into the following steps:

1. Familiarising oneself with the data: We read and re-read the picture books several times to immerse ourselves in the material. These repeated readings helped us to become intimately familiar with the data.

2. Coding the material: The technological content of the books was then dissected into meaningful bits of data in the form of short summarising codes. The codes that we found in the data were of course dependent on our research questions, or as Altrichter, Posch and Somekh (2000) put it, "Categories (features) need to be chosen which are relevant to the research question and at the same time partially express the contents of the data" (p. 124).

3. Identifying the themes: Common themes were extracted and refined from the codes so that they only pertained to one specific idea. The common themes were then organised, depending on similarity, into groupings of main themes and sub-themes.

4. Reviewing the themes: We both separately reviewed the main themes and sub-themes on the basis of their integrity (i.e. that they held up in relation to the coded data). We then compared our reviews and found that some themes "told the same story" and had to be collated into the same theme, while other themes had to be broken down into new themes and sub-themes.

5. Defining and conveying the themes: We then read the books through the lenses of the identified themes and sub-themes and wrote a detailed analysis of each main theme. The themes were described using examples from the text and were contextualised using relevant earlier research.

\section{Results and analysis}

Our examination of the empirical material shows that a large number of the books were written from a perspective of naming, labelling, categorising and giving information about technological artefacts. Through our analysis of the books, three main themes regarding the portrayal of technology emerged: Autonomous technology, Triumphant technology and Technology as an enabler. These overarching themes can then be broken down into subthemes (Table 1). 
Table 1 The main themes and sub-themes derived through the thematic analysis

\begin{tabular}{ll}
\hline Main themes & Sub-themes \\
\hline Autonomous technology & Masculine coded technology \\
& Lack of context \\
& Anthropomorphism \\
& Metaphors \\
Triumphant technology & Western technology \\
& Old versus new technology \\
& Technology and the environment \\
Technology as an enabler & Technological systems \\
& Vocational roles \\
& Female/male dichotomy
\end{tabular}

\section{Autonomous technology}

Motorised vehicles (e.g. cars, airplanes, tractors) are the dominant artefacts on display in the empirical material. These vehicles are often depicted as autonomous; they act without human guidance. This applies to books written both for the youngest (ages 1-3) and the somewhat older (ages 3-6) preschool children. Other artefacts, for example household artefacts, are not as common.

The books aimed at the younger age group deal almost exclusively with traditionally masculine coded technology. Furthermore, humans are frequently excluded and artefacts are presented with a lack of context (in both words and pictures). For example, motorised vehicles are often brightly coloured and set against a small backdrop (e.g. water around a boat, clouds around a plane) or no backdrop at all, and the main focus is on the artefact itself. If humans are presented, they are standing by passively, observing the machine performing the task, or acting as some kind of helper. This can be interpreted as if the technological artefacts operate with a mind of their own; technology is autonomous. This message is often enhanced by the text. Angela Royston's picture books (1991a, b), for example, contain passages like: "Lube trucks deliver oil to where oil is needed" and "The excavating arm is digging large pits". There are however exceptions, like in Anne Gutman's book La Maison (2000), where most of the artefacts are placed in a context.

Similarly to the books for the younger age bracket, the use of a white backdrop is also commonplace in the books catering to the older age group. However, the human interaction with technology is more prominent. Another difference is that the artefacts are often presented with human or animal attributes; anthropomorphism. For example, an engine can be described as "being alert" or as if it is "roaring". In one of the books (Legelius 2011), the car is even described as having a "drummer living under the hood". Metaphors deriving from nature are also common in these books. In Gary Gadget's Best Cars (Johansson and Ahlbom 2004) a disc brake is likened to a "lobster claw" and the exhaust is described as "poop". The message in these books can be interpreted as if the vehicles have a will of their own and act without human control. Overall, just like for the books aimed at ages 1-3, the focus on traditionally masculine coded technology still endures in the books aimed at ages 3-6. An example of one of the few books where traditionally feminine coded technology is highlighted is Bruno the Tailor (Klinting 1996), where the male lead character is sewing an apron. 
Generally, in all of the books, there are many more male than female characters, and the male and female characters have different duties. For example, in Dreer's Oh! Les belles motos (2002), there are about 30 male characters but only a handful of females. The females in the books take on a passive role, standing by and watching the males riding the motorcycles.

In summary, the autonomous depiction of technology is of two kinds. In the books that cater to the youngest, technology is portrayed as autonomous but not in an anthropomorphic way, which instead is how technology is often presented in books for slightly older children. The autonomous and anthropomorphic technology can be interpreted as a way to create an affinity between the reader and the technology. The child is supposed to identify with the technology and connect to it (Axell 2015; Schwarcz 1967). This may not be achieved by the books for the youngest children, where the technology is presented as autonomous and with a lack of context. This conveys a picture of there being a distance between humans and technology. This could be interpreted as technology having a "life" of its own (i.e. it is not a result of human ingenuity and human needs and wants), which can be summed up as a deterministic view of technology (Axell 2015; Ellul 1964). This idea often informs the popular discourse of technological determinism, and is typified by expressions like: "The robots put the riveters out of work", "The machine that changed the world" or "The atomic bomb divested Congress of its power to declare war" (Marx and Smith 1994, p. xi). Statements like this can be interpreted as a technology, once it has been introduced into society, being depicted as taking on a life of its own. In its extreme form, technological determinism means that technology is predetermined to develop in a certain way or pattern, which means that humans have few choices or responsibilities for what is happening. This is in contrast to a belief in human free will and freedom (Pannabecker 1991). Moreover, such a view carries the implication "that the social consequences of our technical ingenuity are far-reaching, cumulative, mutually reinforcing, and irreversible" (Marx and Smith 1994, p. xi). Consequently, a deterministic view of technology and technological development is difficult to reconcile with the democratic aspect of technology education (i.e. creating opportunities for children to develop knowledge to make deliberate choices on technology in the future) (Keirl 2006). Furthermore, the heavy focus on males and masculine coded technology in the books may limit children in what they perceive as potential roads to go down in life. If they are under the impression that things can be categorised as "for boys" or "for girls", their aspirations and career goals can be hindered (Blickenstaff 2006).

\section{Triumphant technology}

Edgerton (2006) notes that the description of technological development is seldom communicated from a global perspective. The history of technology is mainly portrayed in an innovation-centric way, focusing only on the small number of places in the world where the newest inventions and innovations are concentrated. This narrow view is also mediated throughout the picture books; there is a heavy focus on Western technology. In Bergenholz's Vilka bilar (2008), the reader is informed that: "Nowadays almost everyone has a car. Some even have two." This is a generalised statement, considering that the majority of the world's population does not have a car at all.

The historical aspect is a recurrent theme in the picture books, where modern technology is often pitted against older technology. Modern technology is colourfully illustrated whereas the technology of the past is often illustrated in black and white. The message 
is clear: everything has become better. In the past, people had to rely on themselves or animals like horses and oxen. In Bingham's Tractor: Machines at work (2004), for example, the reader is told that harvesting used to be hard and time-consuming work but nowadays we use the tractor, the working horse of today. In the same book, under the headline "Spraying or not", the reader is informed that the crops are sprayed "to grow better". The pictures show how easily the pesticides can be spread over the fields, by just one man and a tractor. There is also a picture from an organic farm showing eight men working behind the tractor, lying on their stomachs and picking weeds. The work on the organic farm is presented as requiring more manpower, and also as being time-consuming. Edgerton (2006) questions the way in which technological development is often described as a historical timeline focusing on certain specific inventions, which are often presented as revolutionary new technology. However, technology does not develop in a vacuum, and the "new" is often about transferring and applying existing knowledge and technology to new uses (Arthur 2011; Edgerton 2006).

There is a lack of recognition of technology's role from an environmental perspective in the books. This is especially true for picture books about motorised vehicles. If the exhaust is mentioned at all it is only as a notion in the vein of "cars pollute the air". Statements in line with "back in the day cars emitted a lot of pollution but today we have ways of fixing this" convey an over-reliance on present and future technology. Negative effects on the environment are not recognised and it is primarily the benefits of technology that are highlighted. A handful of books promote recycling or reusing, but this is only implicit in the texts. However, in Koivisto's book Barnens energibok (2007), energy is described as "[...] a force that allows us to live, grow, play and work. [...] all energy on Earth has its origin from the sun". This book is the only one of the examined books that problematises the use of fossil fuels and uranium, as well as giving suggestions for what people can do in everyday life to save energy.

To sum up, only a few of the 180 picture books raise awareness of technology from a sustainability perspective (i.e. ecological, social and economic sustainability). The majority of the books imply that the most efficient and easiest way of getting things done is to use machines, in this case machines with a heavy impact on the Earth's resources. If we want citizens with a highly developed technological literacy, a literacy that will enable them to make informed everyday decisions regarding technology's impact on the individual, society and the environment, the wider issues of technology (e.g. sustainability and stakeholder interests) are important to highlight (Axell et al. 2014, 2017a; Keirl 2006; Elshof 2009; Mawson 2010). This wider understanding of the nature of technology is something that is not usually picked up by younger children. However, identifying how technology affects everyday life can contribute to more children seeing the value of technology (Mawson 2010, 2013).

\section{Technology as an enabler}

In the books where humans are more frequently active, technology is not autonomous. It is portrayed as a result of a human desire to fulfil needs and wants. The systemic notion of technology is common in these books (e.g. house construction, energy systems, public transportation). This theme is only found in the books aimed at ages 3-6. An example of the interaction between humans and technology appears in Nyfiken på flygplan och raketer (Bessard 2012). The different components of the airport are described, as well as how they are connected. The pages are filled to the brim with different passengers and the employees 
working at the airport. Questions about how to use the airport as a passenger are asked and answered, as well as questions regarding personal safety.

Descriptions of vocational roles and the technology that is linked to these are also common in the books aimed at ages 3-6. These roles are often illustrated using a female character in a traditionally feminine coded occupation and a male character in a traditionally masculine coded one. In Huset mittemot: Hur man bygger ett hus (Suneson and Agdler Suneson 1995), which describes the construction of an apartment building, a multitude of people are shown in a plethora of traditionally masculine coded occupations. Almost all of these characters are male. In Nyfiken på flygplan och raketer (Bessard 2012) there are more male pilots than female ones and the security staff are exclusively men. On one page the reader is encouraged to "find three irregularities". In the picture a stewardess, draped in pink garb, is positioned in the pilot's seat, while the pilot (a male) is relaxing, reading a book in first class.

Males and females are also described differently. An explicit example is Glassfamiljen (Kåberg 2011), which revolves around a family-run ice cream company. Three grown-up siblings working in the factory, a sister and two brothers, are described in the book. The brothers are shown shoulder to shoulder, with text stating that they are in charge of the ice cream production and that they also are the ones who come up with new ice cream flavours. The sister on the other hand is shown with her daughter and her father (the boss at the factory), and the text says nothing about her role at the factory-it only states that she is the mother of the next generation of ice cream makers. This differentiation between women and men is in line with Nikolajeva's (2004) dichotomies of how males and females are usually described in children's literature: males as active and independent, females as passive, caring and dependent. A few books appear to challenge these stereotypes, at least on the surface, for example Bruno the Tailor (Klinting 1996) and Huset mittemot: Hur man bygger ett hus (Suneson and Agdler Suneson 1995). However, when scrutinised further, a gender normative notion emerges in these as well. In Bruno the Tailor (Klinting 1996), the male character is using his aunt's sewing room to make an apron, but his aunt is not a character that has any role in the book. In another book about Bruno (in this translation called Harvey), Harvey the Carpenter (2005), he is making a wooden box. To do this he uses his workshop. The fact that Bruno has to use his aunt's sewing room can be seen as indicating that making an apron is a feminine coded domain, which is in accordance with traditional gender domains regarding technology. The textile industry has, at least since the industrial revolution, been connected to the feminine domain (Berner 2004). In Huset mittemot: Hur man bygger ett hus (Suneson and Agdler Suneson 1995), Engineer Air (a woman) is in charge of making sure that the house will be able to "breathe". She has a traditionally masculine coded occupation but her role is described as caring, in line with a female normative role (Nikolajeva 2004). Her three male engineer colleagues are not described in this way.

\section{Conclusions and implications}

Previous research has shown that there is an emphasis on artefacts and the making of artefacts in technology education. This emphasis also permeated the picture books in our study. This may limit children's holistic understanding of technology. If technology is not placed in a broader context, the connections between artefacts and humans, as well as what kind of implications the artefacts have in a societal context, run the risk of being disregarded. (Axell 2015, 2017a, b; Mawson 2007; Siu and Lam 2005; Svensson 2011). Although books aimed at younger children cannot contain advanced technological concepts, there is a risk 
that the lack of context may prevent children from discovering that technology is part of a larger whole.

The books in this study convey a message that technology has a life of its own and is not linked to human activity, knowledge and volition (i.e. something humans create and use to satisfy needs and wants, or to solve problems). The majority of the picture books, particularly those aimed at younger readers, fail to create a connection between technology and human intentions. On one hand the books can be interpreted as if they want to present technology as being as value-free and as neutral as possible. On the other hand, they miss the opportunity to connect technology to everyday life (i.e. to tie technology to the societal and environmental settings in which they operate).

From a gender perspective, the message in the picture books is clear: Men are both the source of technological development and the users of technology. Male and female characters are often presented in a stereotypical manner and there is also an over-representation of male characters. In the few examples of books where the stereotypes are challenged, there is still an implicit gender normative notion.

As Bjurulf (2011) states, technology education should be conducted on the basis of a holistic approach to learning. When technology is put into a broader perspective, it can contribute to children's understanding of the "made world". For many children, learning about the world starts with picture books, which also often work as an introduction to human application of technology. As gender is something that is mainly socially and culturally created, reading aloud in preschool (which often constitutes the teacher reading the text to the children, while simultaneously showing them the pictures) can encourage children to develop an awareness of gender and how gender patterns are created (SOU 2006:75). After the analysis of about 180 picture books, our conclusion is that, while these may serve as a basis for an introduction to technology, there is also a risk that they will reinforce gender patterns. The way technology is presented in the books, with a heavy focus on males and masculine coded technology, is not in accordance with the goals of the national preschool curriculum, set by the Swedish National Agency for Education. This clearly states that both girls and boys should be given the same opportunities without limitations imposed by stereotyped gender roles. As technology is often presented in a gender normative way in the picture books, it will be up to the preschool teacher to problematise the relationship between technology and gender in these books.

It should be noted that this study is based on children's literature written in a Western cultural context. Based on a view of technology as a product of human beings' social and cultural world, it would be interesting for future research to investigate how technology and technological development are depicted in relation to gender in children's literature in other cultural settings and parts of the world.

Acknowledgements Open access funding provided by Linköping University.

Open Access This article is distributed under the terms of the Creative Commons Attribution 4.0 International License (http://creativecommons.org/licenses/by/4.0/), which permits unrestricted use, distribution, and reproduction in any medium, provided you give appropriate credit to the original author(s) and the source, provide a link to the Creative Commons license, and indicate if changes were made.

\section{References}

Altrichter, H., Posch, P., \& Somekh, B. (2000). Teachers investigate their work: An introduction to the methods of action research. London: Routledge. 
Arthur, W. B. (2011). The nature of technology: What it is and how it evolves. London: Allen Lane.

Attride-Stirling, J. (2001). Thematic networks: An analytic tool for qualitative research. Qualitative Research, 1(3), 385-405.

Axell, C. (2015). Barnlitteraturens tekniklandskap: En didaktisk vandring från Nils Holgersson till Pettson och Findus. [Technology landscapes in children's literature: A didactic journey from Nils Holgersson to Pettson and Findus]. (Doctoral dissertation). Linköping: Linköping University.

Axell, C. (2017a). Critiquing literature: Children's literature as a learning tool for critical awareness. In J. Williams \& K. Stables (Eds.), Critique in design and technology education (pp. 237-254). Singapore: Springer.

Axell, C. (2017b). Technology and children's literature. In M. de Vries (Ed.), Handbook of technology education (pp. 895-911). Cham: Springer.

Axell, C., Hallström, J., \& Hagberg, J.-E. (2014). Images of technology and sustainable development in Swedish children's literature. Australasian Journal of Technology Education, 1(1), 1-9.

Bain, C. D., \& Rice, M. L. (2006). The influence of gender on attitudes, perceptions, and uses of technology. Journal of Research on Technology in Education, 39(2), 119-132.

Bergenholtz, B. (2008). Vilka bilar. Stockholm: Rabén \& Sjögren.

Berner, B. (1999). Perpetuum mobile?: teknikens utmaningar och historiens gång. Lund: Arkiv.

Berner, B. (2004). Ifrågasättanden: Forskning om genus, teknik och naturvetenskap. Linköping: Tema Teknik och social förändring, Linköping University.

Bessard, S., Convert, H., \& Giubbaud, C. (2012). Nyfiken på flygplan och raketer. Stockholm: Bonnier Carlsen.

Bingham, C. (2004). Tractor: Machines at work. London: DK Publishing.

Björndahl, C. R. P. (2005). Det värderande ögat: Observation, utvärdering och utveckling $i$ undervisning och handledning. Stockholm: Liber.

Bjurulf, V. (2011). Teknikdidaktik. Stockholm: Norstedt.

Blickenstaff, J. C. (2006). Women and science careers: Leaky pipeline or gender filter? Gender and Education, 17(4), 369-386.

Boström, J. (2018). Teknik i förskolan: Att motverka traditionella könsroller. Linköping: Linköping University.

Boyatzis, R. E. (1998). Transforming qualitative information: Thematic analysis and code development. London: Thousand Oaks.

Braun, V., \& Clarke, V. (2008). Using thematic analysis in psychology. Qualitative Research in Psychology, 3(2), 77-101.

Browne, N., \& Ross, C. (1991). Girls' stuff, boys' stuff: Young children talking and playing. In N. Browne (Ed.), Science and technology in the early years: An equal oppurtunities approach (pp. 37-51). Milton Keynes: Open U.P.

Cai, Z., Fan, X., \& Du, J. (2017). Gender and attitudes toward technology use: A meta-analysis. Computers \& Education, 105, 1-13.

Clark, R., Guilmain, J., Saucier, P. K., \& Tavarez, J. (2003). Two steps forward, one step back: The presence of female characters and gender stereotyping in award-winning picture books between the 1930s and the 1960s. Sex Roles, 49(9-10), 439-449.

Cockburn, C. (1985). Machinery of dominance: Women, men and technical know-how. London: Pluto Press.

Cockburn, C., \& Ormrud, S. (1983). Gender and technology in the making. London: Sage.

Crisp, T., \& Hiller, B. (2011). 'Is this a boy or a girl?': Rethinking sex-role representation in caldecott medal-winning picturebooks, 1938-2011. Children's Literature in Education, 42(3), 196-212.

Dreer, F. (2002). Oh! Les belles motos. Ca roule.

Edgerton, D. (2006). The shock of the old: Technology and global history since 1900. London: Profile Books.

Eidevald, C. (2009). Det finns inga tjejbestämmare: Att förstå kön som position i förskolans vardagrutiner och lek. Jönköping: Jönköping University.

Ellul, J. (1964). The technological society. New York: Vintage Books.

Elshof, L. (2009). Toward sustainable practices in technology education. International Journal of Technology and Design Education, 19(2), 133-147.

Faulkner, W. (2001). The technology question in feminism: A view from feminist technology studies. Women's Studies International Forum, 24(1), 79-95.

Foster, P. N. (2009). An analysis of children's literature featured in the "books to briefs" column of technology and children, 1998-2008. Journal of Technology Education, 21(1), 25-43. 
Freeman, N. K. (2007). Preschoolers' perceptions of gender appropriate toys and their parents' beliefs about genderized behaviors: Miscommunication, mixed messages, or hidden truths? Early Childhood Education Journal, 34(5), 357-366.

Gooden, A. M., \& Gooden, M. A. (2001). Gender representation in notable children's picture books: 1995-1999. Sex Roles, 45(1-2), 89-101.

Gutman, A. (2000). La maison. Paris: Hachette Jeunesse.

Hallberg, K. (1982). Litteraturvetenskapen och bilderboksforskningen. Tidskrift för litteraturvetenskap, 1982(3-4), 163-168.

Hallberg, K. (2008). Kom an, Alfons Åberg! En studie av Gunilla Bergströms bilderbokssvit. In M. Andersson \& E. Druker (Eds.), Barnlitteraturanalyser (pp. 9-26). Lund: Studentlitteratur.

Hamilton, M. C., Anderson, D., Broaddus, M., \& Young, K. (2006). Gender stereotyping and underrepresentation of female characters in 200 popular children's picture books: A twenty-first century update. Sex Roles, 55(11-12), 757-765.

Hellsing, L. (1999). Tankar om barnlitteraturen (New ed.). Stockholm: Rabén \& Sjögren.

Ihde, D. (1993). Philosophy of technology: An introduction. New York: Paragon House Publishers.

Johansson, G., \& Ahlbom, J. (2004). Mulle Mecks bästa bilar. Stockholm: Natur och Kultur.

Kåberg, C. (2011). Glassfamiljen. Stockholm: LL-förlaget.

Kåreland, L. (2005). Modig och stark-eller ligga lågt: skönlitteratur och genus i skola och förskola. Stockholm: Natur och kultur.

Kåreland, L. (2013). Barnboken i samhället (2nd ed.). Lund: Studentlitteratur.

Keirl, S. (2006). Ethical technological literacy as democratic curriculum keystone. In J. R. Dakers (Ed.), Defining technological literacy: Towards an epistemological framework (pp. 81-102). New York: PalgraveMacmillan.

Kimmel, M. S. (2000). The gendered society. New York: Oxford University Press.

Klinting, L. (1996). Bruno the tailor. NewYork: Henry Holt \& Co.

Klinting, L. (2005). Harvey the carpenter. London: Kingfisher Books Ltd.

Koivisto, T. (2007). Barnens energibok. Helsingfors: Lasten Keskus.

Legelius, C. (2011). Paddan, Bubblan och Kojan-bilar som blivit klassiker. Berghs.

Lyon, E. (1991). The role of the nursery school in developing a non-sexist approach to science and technology. In N. Browne (Ed.), Science and technology in the early years: An equal oppurtunities approach (pp. 67-76). Milton Keynes: Open U.P.

MacNaughton, G. (1997). Who's got the power? Rethinking gender equity strategies in early childhood. International Journal of Early Years Education, 5(1), 57-66.

Marx, L., \& Smith, M. R. (1994). Introduction. In M. R. Smith \& L. Marx (Eds.), Does technology drive history? The dilemma of technological determinism (pp. 9-25). Cambridge, MA: MIT Press.

Mawson, B. (2007). Factors affecting learning in technology in the early years at school. International Journal of Technology and Design Education, 17(3), 253-269.

Mawson, B. (2010). Children's developing understanding of technology. International Journal of Technology and Design Education, 20(1), 1-13.

Mawson, B. (2013). Emergent technological literacy: What do children bring to school? International Journal of Technology and Design Education, 23(1), 443-453.

McLean, K., Jones, M., \& Schaper, C. (2015). Children's literature as an invitation to science inquiry in early childhood education. Australasian Journal of Early Childhood, 40(4), 49-56.

Mellström, U. (2003). Teknik och maskulinitet. In B. Berner (Ed.), Vem tillhör tekniken?: Kunskap och kön i teknikens värld (pp. 57-76). Lund: Arkiv förlag.

Mellström, U. (2004). Machines and masculine subjectivity: Technology as an integral part of men's life experiences. Men and Masculinities, 6(4), 368-382.

Monhardt, L., \& Monhardt, R. (2006). Creating a context for the learning of science process skills through picture books. Early Childhood Education Journal, 34(1), 67-71.

Murphy, P. (2006). Gender and technology: Gender meditation in school knowledge construction. In J. R. Dakers (Ed.), Defining technological literacy: Towards an epistemological framework (pp. 219-237). New York: Palgrave MacMillan.

Nikolajeva, M. (2000). Bilderbokens pusselbitar. Lund: Studentlitteratur.

Nikolajeva, M. (2004). Barnbokens byggklossar. Lund: Studentlitteratur.

Nisbet, M., Pendergast, D., \& Reynolds, J. (1998). Keeping gender on the technology education agenda: An issues paper. Journal of the Home Economics Institute of Australia, 5(1), 23-32.

Oldenziel, R. (1999). Making technology masculine: Men, women and modern machines in America, 1870-1945. Amsterdam: Amsterdam University Press.

Oskamp, S., Kaufman, K., \& Wolterbeek, L. Atchison. (1996). Gender role portrayals in preschool picture books. Journal of Social Behavior and Personality, 11(5), 27-39. 
Pannabecker, J. R. (1991). Technological impacts and determinism in technology education: Alternate metaphors from social constructivism. Journal of Technology Education, 3(1), 43-54.

Paynter, K. C. (2011). Gender stereotypes and representation of female characters in children's picture books. Lynchburg: Liberty University.

Pearson, L. (2011). Children's literature: Texts, contexts, connections. London: York Notes.

Raag, T., \& Rackliff, C. L. (1998). Preschoolers' awareness of social expectations of gender: Relationships to toy choices. Sex Roles: A Journal of Research, 38(9-10), 685-701.

Reynolds, K. (2011). Introduction. In K. Reynolds \& M. O. Grenby (Eds.), Children's literature studies: A research handbook (pp. 1-10). Basingstoke: Palgrave Macmillan.

Rohaan, E., Taconis, R., \& Jochems, W. (2010). Reviewing the relations between teachers' knowledge and pupils' attitude in the field of primary technology education. International Journal of Technology and Design Education, 20(1), 15-26.

Ross Johnston, R. (2011). Gender. In K. Reynolds \& M. O. Grenby (Eds.), Children's literature studies: A research handbook (pp. 151-161). Basingstoke: Palgrave Macmillan.

Royston, A. (1991a). Bilar. Uppsala: Hjelm.

Royston, A. (1991b). Grävare och lastare. Uppsala: Hjelm.

Sackes, M., Trundle, K. C., \& Flevares, L. M. (2009). Using children's literature to teach standard-based science concepts in early years. Early Childhood Education Journal, 36(5), 415-422.

Sandnabba, K. N., \& Ahlberg, C. (1999). Parents' attitudes and expectations about children's cross-gender behavior. Sex Roles, 40(3-4), 249-257.

Schwarcz, J. H. (1967). Machine animism in modern children's literature. The Library Quarterly, 37(1), 78-95.

Simonsson, M. (2004). Bilderboken i förskolan: En utgångspunkt för samspel. Linköping: Linköping University.

Siu, K. W. M., \& Lam, M. S. (2005). Early childhood technology education: A sociocultural perspective. Early Childhood Education Journal, 32(6), 353-358.

SOU 2006:75. (2006). Jämställdhet i förskolan—om betydelsen av jämställdhet och genus i förskolans pedagogiska arbete. Stockholm: Fritzes Offentliga Publikationer.

Suneson, A., \& Agdler Suneson, E. (1995). Huset mittemot: Hur man bygger ett hus. Stockholm: Rabén \& Sjögren Bokförlag.

Svenningsson, J., Hultén, M., \& Hallström, J. (2018). Understanding attitude measurement: Exploring meaning and use of the PATT short questionnaire. International Journal of Technology and Design Education, 28(1), 67-83.

Svensson, M. (2011). Att urskilja tekniska system: Didaktiska dimensioner i grundskolan. Linköping: Linköping University.

Swedish National Agency for Education. (2018). Curriculum for the Preschool Lpfö (Vol. 18). Stockholm: Skolverket.

Trepanier-Street, M. L., \& Romatowski, J. A. (1999). The influence of children's literature on gender role perceptions: A reexamination. Early Childhood Education Journal, 26(3), 155-159.

Trundle, K. C., \& Troland, T. H. (2005). The moon in children's literature. Science and Children, 43(2), 40-43.

Turja, L., Endepohls-Ulpe, M., \& Chatoney, M. (2009). A conceptual framework for developing the curriculum and delivery of technology education in early childhood. International Journal of Design and Technology Education, 19(4), 353-365.

Volk, K., \& Ming, Y. (1999). Gender and technology in Hong Kong: A study of pupils' attitudes toward technology. International Journal of Technology and Design Education, 9(1), 57-71.

Volman, M., Eck, E. V., \& Dam, G. T. (1995). Girls in science and technology: The development of a discourse. Gender and Education, 7(3), 283-292.

Wajcman, J. (1991). Feminism confronts technology. Cambridge: Polity Press.

Westin, B. (2003a). Karlsson som technobody. Tidskrift för litteraturvetenskap, 32(4), 128-142.

Westin, B. (2003b). Världens bästa Karlsson: Barnlitteratur och teknologi. Nordisk tidskrift för vetenskap, konst och industri, 2003(79), 293-300.

Publisher's Note Springer Nature remains neutral with regard to jurisdictional claims in published maps and institutional affiliations. 